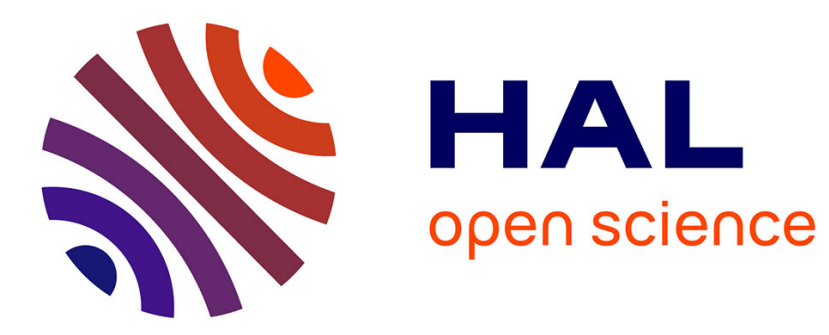

\title{
Pastiche, Collage, and Bricolage: Caryl Phillips' Hybrid Journal and Letters of a Slave Trader in Crossing the River
}

\author{
Vanessa Guignery
}

\section{To cite this version:}

Vanessa Guignery. Pastiche, Collage, and Bricolage: Caryl Phillips' Hybrid Journal and Letters of a Slave Trader in Crossing the River. ariel: A Review of International English Literature, 2018, 49 (2-3), pp.119-148. 10.1353/ari.2018.0015 . hal-02426138

\section{HAL Id: hal-02426138 \\ https://hal.science/hal-02426138}

Submitted on 1 Jan 2020

HAL is a multi-disciplinary open access archive for the deposit and dissemination of scientific research documents, whether they are published or not. The documents may come from teaching and research institutions in France or abroad, or from public or private research centers.
L'archive ouverte pluridisciplinaire HAL, est destinée au dépôt et à la diffusion de documents scientifiques de niveau recherche, publiés ou non, émanant des établissements d'enseignement et de recherche français ou étrangers, des laboratoires publics ou privés. 


\title{
Pastiche, Collage, and Bricolage: \\ Caryl Phillips' Hybrid Journal and Letters \\ of a Slave Trader in Crossing the River
}

\section{Vanessa Guignery}

ARIEL: A Review of International English Literature, Volume 49, Number 2-3, April-July 2018, pp. 119-148.

Published by Johns Hopkins University Press

https://doi.org/10.1353/ari.2018.0015

\begin{abstract}
In the third narrative of Crossing the River, which includes Captain Hamilton's edited journal of his voyage to West Africa and correspondence to his wife, Caryl Phillips uses both pastiche - through the imitation of the style of John Newton's authentic logbook, Journal of a Slave Trader (1750-54), and of Newton's letters to his wife - and a montage or collage through the inclusion of barely amended extracts from Newton's original documents. Critics disagree about the proportion of appropriation and creation in this third section; some highlight the novelist's creative transformation and transposition of the historical documents while others insist that Phillips relies excessively on the original text while simultaneously reducing its complexities. I argue that Phillips' faithfulness to the original enables him to preserve the memory of the slave trade in its sheer horror, while his deviations from Newton's journal and letters point to the instability of any text, be it historical or fictional. The insertion of this section within a novel in which other parts are more clearly fictional and involve former slaves draws attention not only to the constructedness of any discourse but also to the different textual means through which the past can be remembered.
\end{abstract}

Keywords: slavery, pastiche, journal, Caryl Phillips, Crossing the River

Caryl Phillips' fifth novel Crossing the River (1993) is often studied alongside neo-slave narratives, but recent criticism has emphasized the 
diasporic scope of the novel in which slavery is a major, but not the main, topic (Wallart 261). Slavery is nevertheless at the heart of the third section of the novel, which is titled "Crossing the River" and consists of the logbook of a fictional slave trader, James Hamilton, during his expedition to the west coast of Africa in 1752-53 as well as two letters to his wife. From the sixteen months of extensive research Phillips conducted before he started writing the book (Phillips, "Crossing" 26), he singled out one specific document mentioned in the acknowledgements: Journal of a Slave Trader (1750-54) by John Newton (1725-1807). Through this paratext, the novel, like its predecessor Cambridge (1991), "deliberately calls attention to its intertextuality" (O'Callaghan 34) and thus does not smuggle its major hypotext. According to Gérard Genette, hypertextuality involves a process of grafting a new text onto an earlier text ${ }^{1}$ and can include transformation (through parody) and imitation (through pastiche); "Crossing the River" both transforms the hypotext and employs pastiche through its imitation of the style of Newton's authentic logbook and the letters to his wife (an unacknowledged source in the paratext). This third section is also characterised by a montage or collage through its inclusion of slightly modified extracts from Newton's original documents without quotation marks. $^{2}$ This article examines Phillips' ventriloquism of this eighteenthcentury English slave captain and reflects on how a contemporary novel may bear witness to the trauma of slavery by borrowing from historical documents (thus preserving the memory of the past) and adding fictional elements which point to the constructedness of any discourse.

Crossing the River weaves together four narratives of forced displacement, throwing light on emancipated slaves' journeys from America to Africa in the nineteenth century in Part I, "The Pagan Coast"; the ordeal of a former slave turned frontierswoman and defeated pioneer in the American Wild West in Part II, "West"; the slave trade in Africa in the eighteenth century in Part III, "Crossing the River"; and the alienation of an Englishwoman and a black GI in England during the Second Word War in Part IV, "Somewhere in England." Spanning three centuries and crisscrossing three continents, Crossing the River raises crucial questions related 
to identity, belonging, uprootedness, responsibility, and loss. It is an interesting coincidence that Phillips' novel was published in the same year as Paul Gilroy's The Black Atlantic: Modernity and Double Consciousness since both novelist and theoretician draw on the cultural memory of slavery to reflect on the traces it has left in the contemporary world.

"Crossing the River" is not the only case of extensive borrowing from historical documents in Phillips' work; he also developed a complex network of unmarked quotations from various authentic sources in Cambridge and in The Nature of Blood (1997). ${ }^{3}$ Critics who have analysed "Crossing the River" and (more frequently) Cambridge have dismissed any charge of plagiarism since the hypotext is ostentatiously identified from the start. However, they have disagreed about the proportion of appropriation and creation in both texts. Some insist on the creative transformation and transposition of the historical documents, ${ }^{4}$ thus situating Phillips within a postcolonial and postmodernist tradition of reworking past authoritative texts, while othersmost notably Marcus Wood in his incisive comparison of the original and invented journal and letters-argue that Phillips relies excessively on the original text while simultaneously reducing its complexities. Scholarly debate also exists over Phillips' choice to prioritize a white male voice and perspective on the slave trade in a section that keeps the slaves in the cargo hold resolutely silenced.

After discussing the text's historical context, this analysis focuses on the contradictions that emerge from the coexistence of the logbook and the letters in "Crossing the River" and complicate the reader's response to the characterisation of the captain. It compares the writings of the authentic and fictional slave ship captains - both in the logbooks and the letters - in order to evaluate the proportion of creation in the novel. In particular, I show how Phillips' faithfulness to the original allows him to give the reader a sense of the cruelty of the slave trade while his deliberate omissions point to all that is left unsaid by official documents. The article concludes by suggesting that this controversial case of bricolage inserted within a work of fiction is valuable for the way it preserves the cultural memory of slavery while hinting at the limitations of the historical archive. 


\section{The Slave Ship Captain's Mighty Contradictions}

Phillips conducts substantive research as preparation for his novels and often relies on historical sources. He is particularly fond of first-person historical documents which he draws from to "digest what they're saying, and somehow rework them" (Phillips, "Of This Time" 32). This reworking usually entails paying close attention to their form since "all too often there's a self-serving nature behind these narratives" (31). Referring to diaries and journals written by slave ship captains, Phillips notes in an interview with Pico Iyer: "[T]here is always an agenda, which is obviously part and parcel of the economic and political purpose behind that journey" ("Caryl Phillips" 43). In "Crossing the River," Phillips is interested in uncovering the agenda in Newton's Journal of a Slave Trader, a day-to-day record of three different voyages made by a slave ship Newton captained from Liverpool to the Windward Coast of Africa, then Antigua, and back to Liverpool. Newton's first journal relates his voyage on the Duke of Argyle (1750-51), which was undertaken at a time when the slave trade was, according to the editors of Newton's journal, deemed "respectable" and necessary to England's economy (Martin and Spurrell in Newton, Journal xi). Newton had no issue engaging in a trade he called "a genteel employment" (qtd. in Wood 43). It was only when writing An Authentic Narrative (1764) that he started to express doubts about the morality of the enterprise. In Thoughts Upon the African Trade (1788), he considered it "unlawful and wrong" and admitted to being haunted in his old age by memories of a "business at which my heart now shudders" (Newton, Journal 99, 98). However, prior to his transformation into a dedicated abolitionist, Newton had no such qualms about what he later called "that unhappy and disgraceful branch of commerce" (98). His account of his first voyage provided Phillips with the inspiration for "Crossing the River."

What struck Phillips about Newton's situation and which he reproduced in the creation of his fictional Captain James Hamilton was the paradoxical situation of a man who was simultaneously "wreaking havoc on other people's families" and "dreaming of beginning a family of his own" (Phillips, "Of This Time" 32). Indeed, while writing his logbook, which dispassionately 
records the relentless buying of slaves and sundering of family ties, their illnesses and deaths, and the impact of these losses on his own profit, Newton was also writing long affectionate letters to his wife in England, Mary (née Catlett). As Phillips notes, Newton “can't recognize his own contradictions, but hopefully we can" ("Of This Time" 32). Phillips works to unveil these contradictions by juxtaposing the impersonal, chilling tone of Hamilton's journal with the effusive style of his letters. While the twenty-six-year-old Hamilton ruthlessly destroys families through the slave trade - an act that is recurrently displayed throughout the novel and presented as a constitutive trauma of slavery - he simultaneously longs for the love of his wife and mourns the death of his father, which occurred two years before in West Africa and was "a mighty severe" blow and the first one he felt keenly, having been "too young to fully grieve" for the death of his mother (Phillips, Crossing the River 118, 120). Bereft of father and mother as are other characters in the novel (especially slaves), the young Hamilton "revels in the imagined joys" of his "projected children" (120) but fails to notice his own rupturing of family lines. Phillips observes: “As black people's lives were being subjected to all these forces - the dispersal, the brutality, the historical hurt-white people were still dreaming of having families, of bringing up their kids, and of what schools they were going to send them to. They couldn't actually see the people before them as human beings, as fathers, brothers, mothers, daughters, sons." ("Of This Time" 32) This paradox looms large in one of Newton's letters to his wife, written in January 1753, when he argues that "these poor creatures" (Letters 157) do not understand love: "To tell them of the inexpressible, and peculia [sic] attraction, between kindred minds; the pains of absence, the pleasures of a re-meeting (if I may make a word,) and all the other endearments, (were it lawful, or possible to name them,) which I owe to you, would be labour lost" (160). Newton's assumption that the slaves do not understand "the pains of absence" is bitterly ironic when compared to authentic documents by former slaves ${ }^{5}$ as well as the fictional narrative of former slave Martha, who is haunted by the painful memory of her lost daughter, in Part II of Crossing the River. ${ }^{6}$ In his letter to his wife, Newton suggests that he discussed the topic of love with the slaves: he has "tried to 
explain this delighted word" to them (Letters 159), has "spoken of its effects" (160), and the slaves have responded to his observations but without understanding or believing him. Such a claim sounds doubtful considering the type of relationships the captain would have had with the slaves and the way they were usually deprived of a voice (as registered in "Crossing the River"). Newton's self-delusion therefore seems blatant, not only at the time of writing the letters, but also forty years later when, in a footnote to his letter, he starts "with horror at [his] own employment, as an agent in promoting ... this vile traffic" and yet writes: "I only thought myself bound to treat the slaves under my care with gentleness, and to consult their ease and convenience, as far as was consistent with the safety of the whole family, of whites and blacks, on board my ship" (158; emphasis added). The ironic notion of a "family, of whites and blacks" on the slave ship - all of them seemingly treated equally and with great care-suggests that Newton's blindness persisted even during his efforts toward the abolition of slavery.

In Phillips' novel, the coexistence of two literary genres (the clinical log and the sentimental letter) that reflect the two sides of Hamilton's personality is emblematic of the captain's schizophrenic resolution to "separate the two aspects of his life - the domestic and the vocational" (Bellamy 132). ${ }^{7}$ Hamilton's capacity to write himself "into tears" out of love and longing for his wife (Crossing the River 110) and soon after coldly and tearlessly record the numbers of the slaves who died and were thrown overboard can be compared to George Steiner's comment that "a man can read Goethe or Rilke in the evening, ... can play Bach and Schubert, and go to his day's work at Auschwitz in the morning" (ix). This comparison between slavery and the Holocaust is not fortuitous; in The Nature of Blood, Phillips weaves connections between the experiences of loss suffered by Jews and Blacks at the hands of Janus-like persecutors. Hamilton's situation can be related to Hannah Arendt's concept of the "banality of evil" in Eichmann in Jerusalem (1963), in which she argues that Adolf Eichmann was an average man and "not a "monster"” (55), someone who, like Hamilton, unthinkingly supervised "the routine organization of dehumanization" (Lanone 67). Eichmann's inability "to think from the standpoint of someone else" (Arendt 49) and his 
reliance on stock phrases and clichés during his trial are echoed in Hamilton's failure to acknowledge the suffering and odious treatment of the slaves and his mechanical transcription of purchases, illnesses, and deaths.

The reader would judge it difficult to find any redeeming trait in Hamilton's personality. Even the letters to his wife ring hollow in their gushy sentimentalism, and most critics emphasize the slave captain's coldbloodedness and brutality (Bellamy 132; Boutros 184; Lanone 66; Ledent 59; Ward, Caryl Phillips 54). However, Fatim Boutros offers what he calls "a more nuanced understanding" (184) of the captain's social position by arguing that in the logbook and in front of his crew-who repeatedly question his authority and mock him-Hamilton has "to live up to what is expected of a captain, which conflicts with his private character" (184) and his Christian beliefs. His letters to his wife reveal the "mental strain" induced by what is expected of those involved in the slave business, which breaks men physically and spiritually. According to Boutros, Hamilton's "sense of inadequacy . . . complicate[s] stereotypical views of victims and perpetrators" (184). Phillips' interest in the character reflects this view:

I can feel . . . compassion for and interest in a slave ship captain because not only do I have the evidence that some slave ship captains deeply repented and in the end wrote narratives against the slave trade, I could also imagine the slave ship captain finding himself in this position through no fault of his own. I could also imagine that even somebody cruel could find themselves justifying what they were doing because of economic necessity or economic greed. ("Disturbing” 62)

This understanding explains Phillips' choice to give a voice to the slave trader as well as victims of slavery such as Nash in Part I of the novel and Martha in Part II, a decision for which Phillips was taken to task by such critics as Yogita Goyal and Timothy Bewes. Bewes is uneasy about the fact that “Phillips's work 'humanizes' even the characters who seem most fully implicated in the slave trade" (49) and cites the example of Captain Hamilton; he adds that the novel "offers a structure in which, seemingly, each of the children sold into slavery in the opening pages will successively speak his or 
her experience, but in fact none of them does" (49). Goyal worries that the novel "attributes a narrative of moral growth to white characters" (20) while simultaneously silencing the slaves' narratives and thus reproducing the privilege given to white master discourses in official historiography.

Phillips' decision to give Hamilton a dominant voice in this section as well as borrow so much from Newton's original journal and letters necessarily raises ethical questions. While Part I of the novel is limited to pastiche in the form of Nash's imitation and appropriation of Western Christian colonial discourse, Part III combines stylistic imitation with unamended quotations. Newton's journals are sometimes reproduced almost word for word. Abigail Ward notes that the faithful reliance on the narratives of slave captains or plantation owners demonstrated by postcolonial authors such as Phillips can be troubling "because of the possibility of transforming these documents into monuments" and "bestowing upon them a new kind of authority in the twentieth or twenty-first centuries" ("Postcolonial" 247, 248). Extreme loyalty to the archive risks allowing these voices to dictate the way the memory of the slave trade is recorded and perpetuating the silencing of the victims. A comparison of Newton's authentic journal and Hamilton's fictional one reveals that Phillips substantially relied on the hypotext but that this faithfulness to the original can work as a powerful means of denunciating the dehumanizing process of the slave trade and preserves traces of such shameful deeds.

\section{The Silences of the Logbooks}

As the editors of Newton's journal note, authentic logbooks had to record the winds and currents met by the ship, provide an account of the boats and lands sighted, and document the general condition of the crew and ship (Newton, Journal xvi). They were also "an exercise in bookkeeping, saying who was bought when and where, how much was paid" and thus served as "economic testimony" (Wood 57). These logs (which were not meant to be published) were handed over to the owners of the ship at the end of the voyage, which explains why the captain is focused on highlighting his business skills, justifying his losses, and reassuring his readers as to his wise decisions. 
Phillips' fictional logbook offers a very faithful pastiche of such official documents, with a few sometimes meaningful transformations. Hamilton's voyage starts on 24 August 1752, thus overlapping with Newton's second voyage of 1752-53, but Phillips' entries borrow from the logbooks of the three voyages undertaken by Newton between 1750 and 1754 - mainly the first and second-and sometimes blend several entries.

Both the authentic and fictional journals have similar title pages and crew lists, which comprise their names, occupations, and the dates of their death or discharge. Phillips borrowed eleven names from Newton's journal for the first voyage - although he modified the first names - thus making his borrowings easily discernible. ${ }^{8}$ The journal entries themselves are similar as most of them include the day of the week, date, and month in italics, followed by descriptions of the weather. Newton and Hamilton both refer to repairs on the ship, meeting other ships, arriving in West Africa, meeting slave traders, and buying and refusing slaves. The entries are composed with the same staccato rhythm and impersonal tone. Beyond presentation and content, entries often contain the same words, phrases, and structure. This ensures that Phillips adequately pastiches the eighteenth-century British language used by a captain, but it also suggests that what is at stake is an acknowledgment of past literature and the memory of the slave trade. By replicating the authentic logbook with slight revisions, Phillips preserves traces that testify to the horrors of the slave trade.

Similarities in phrasing relate to everyday activities on the ship:

\begin{tabular}{|c|c|c|}
\hline & Newton's Journal & Hamilton's Journal \\
\hline 1. & $\begin{array}{l}4^{\text {th }} \text { October [1750]: "Carpenter } \\
\text { employed in fitting up the } \\
\text { stateroom to serve as a shop on the } \\
\text { Coast" (10). }\end{array}$ & $\begin{array}{l}6^{\text {th }} \text { October }[1752]: \text { "Carpenter } \\
\text { fitted up state room to serve as a } \\
\text { shop on the Coast" }(102) .\end{array}$ \\
\hline 2. & $\begin{array}{l}5^{\text {th }} \text { October: "[R]emoved most of } \\
\text { the India cloth. ... [G]ot the ship's } \\
\text { arms chest aft. Were all hand so } \\
\text { engaged..." (10). }\end{array}$ & $\begin{array}{l}6^{\text {th }} \text { October: "Removed most of } \\
\text { India cloth from hold into cabin. } \\
\text { Got ship's arms chest aft. . . All } \\
\text { hands engaged ..." (102). }\end{array}$ \\
\hline
\end{tabular}




\begin{tabular}{|c|c|c|}
\hline 3. & $\begin{array}{l}\text { 10 October: "Caught a small } \\
\text { dolphin" (10). }\end{array}$ & $\begin{array}{l}11^{\text {th }} \text { October: "Caught a small } \\
\text { shark" (103). }\end{array}$ \\
\hline 4. & $\begin{array}{l}12^{\text {th }} \text { October: "[A] great deal of } \\
\text { lightning and thunder. Very strong } \\
\text { riplings" (10). }\end{array}$ & $\begin{array}{l}11^{\text {th }} \text { October: "By } 2 \text { p.m. a great } \\
\text { deal of lightning and thunder. } \\
\text { Very strong riplings ..." (103). }\end{array}$ \\
\hline 5. & $\begin{array}{l}16^{\text {th }} \text { October: "At } 2 \text { p.m. got } \\
\text { soundings again about } 30 \text { fathoms, } \\
\text { white sand and black stones" (11). }\end{array}$ & $\begin{array}{l}11^{\text {th }} \text { October: "Got soundings at } \\
\text { about } 35 \text { fathoms, white sand } \\
\text { and black stones" (103). }\end{array}$ \\
\hline
\end{tabular}

Apart from a few alterations of dates and the substitution of a harmless "dolphin" for a more threatening "shark," the entries look very similar. Phillips thereby remains loyal to the original text. However, not all entries are so benign. Several draw attention to tensions on board, even before the arrival of slaves. In both journals, for instance, the boatswain behaves badly and is clapped in irons, a punishment that anticipates what would happen to the slaves:

24th October [1750]: [T]he offisers [sic] and all the ship's company to a man complained that the Boatswain has behaved very turbulently, and used them ill, to the hindrance of the ship's business. Having passed by several of the like offences before, I thought it most proper to put him in irons, in terrorem, being apprehensive he might occasion disturbance, when we get slaves on board. (Newton, Journal 12)

$14^{\text {th }}$ October [1752]: Upon my return the ship's company, to a man, complained that in my absence the Boatswain, Mr Davy, had used them ill. I thought it proper to put him in chains lest he might occasion disturbance when we get slaves on board. (Phillips, Crossing the River 103)

Despite the use of the same vocabulary, Phillips' version is much terser and denser. The information that the boatswain has been put in chains may come as a shock for the reader after receiving the vague information that he "had used [the ship's company] ill," whereas Newton proposes four consecutive 
reasons for putting the boatswain in irons, thus making sure his ship-owning readers would approve of his decision. The fictional captain therefore appears more implacable in his decision, which constitutes a slight deviation from the original. In addition to being put in irons for bad behavior, members of the crew become sick and die, as is bluntly noted in both logbooks:

$11^{\text {th }}$ January [1751]: At 2 a.m. departed this life Andrew Corrigal, our carpenter, having been 10 days ill of a nervous fever; buried him at daylight. (Newton, Journal 30)

23rd April [1753]: At 7 p.m. departed this life Edward White, Carpenter's Mate, 7 days ill of a nervous fever. Buried him at once. (Phillips, Crossing the River 116)

Both entries are marked by an informal tone and a lack of emotion. ${ }^{9}$ However, Phillips' version is once again brisker: the Carpenter's Mate dies more quickly (after seven days of illness rather than ten) and is buried more quickly ("at once" rather than "at daylight"). This sense of urgency may be linked to the very form of the novel, which has to incorporate so many different voices that Hamilton's logbook must be dense and efficient, but it again impacts the text's characterization of Hamilton, who seems more ruthless or uncaring toward the crew than his authentic predecessor. ${ }^{10}$ I interpret these minimal (but crucial) changes of names, statuses, times, and dates as signs of the shift from the historical to the fictional.

One of the differences between the journals is that Hamilton makes a number of references to problems with the crew while Newton rarely does, perhaps because he wants to convince his readers of the good conduct of his employees (even if several were discharged, as indicated on his crew list [Newton, Journal 2]). The cases of misbehavior on the part of the crew can be partly attributed to the fact that it was increasingly difficult to recruit sailors for such voyages and the crew was often made up of "refuse from prisons or drinking houses" (Phillips, The Atlantic 42). As Newton notes in an unpublished letter from 1752, "We are for the most part supplied with the refuse and dregs of the nation. The prisons and glass houses furnish us with 
large quotas and boys impatient of their parents and masters, or already ruined by some untimely vice and for the most part devoid of all good principles" (Newton, Journal xiv). Few volunteered to take part in such journeys; sailors were exposed to many diseases during the months of trading off the coast of West Africa and were often punished when on board (as illustrated in Crossing the River). When Newton gave evidence to a Committee of the House of Commons in 1790, he declared: "I suppose there is no trade in which seamen are treated with so little humanity" (Newton, Journal xiv). That Phillips devotes more entries to the crew than does the original journal suggests that he is as interested in the fate of the voiceless sailors as he is in that of the slaves. He underscored this notion in an interview:

The experience of the sailor on deck is as important as the experience of the slave below deck. That experience of the young boy press-ganged at eleven onto a ship, suddenly finding himself sailing the Atlantic backwards and forwards and dead at seventeen from malaria on the coast somewhere three thousand miles from home and his family is as valid an experience as what happened to the slave below deck. ("Disturbing" 65)

The helpless sailors may be subaltern figures, but they are still relatively free, to the point that some of them escape (in the novel, the sailors Cropper and Creed manage to run away with the yawl) — an impossibility for the chained slaves in the hold. Ward writes that it is therefore "problematic to compare too closely enslaved Africans with free, if harshly treated, white crew members" (Caryl Phillips 55). Additionally, although the sailors are not given a voice in the logbooks, they are at least named, while the slaves remain nameless and voiceless. Phillips' use of the genres of the journal and the letters also limits the section's viewpoint and voice to the captain, thereby perpetuating the silencing of the slaves. ${ }^{11}$ Unlike the other three narratives contained in the novel, in "Crossing the River" slaves are not identified by name, remain mute, and are mere commodities considered only as numbered items in a group. In an entry in Hamilton's journal, for example, the primacy of numerical details and categorization according to gender and age deprive 
the slaves of their individuality and humanity: "32 slaves viz. 19 men, 3 manboys, 4 women, and 6 girls" (Phillips, Crossing the River 122). Such silencing and objectification of slaves is typical of master discourses of official history, which Phillips reproduces in this section in order to expose their cold factuality and brutality. Postcolonial writing interrogates and subverts such discourses and offers in their place the forgotten voices of history, as is the case in Part II of Crossing the River, "West," in which a former slave woman is allowed to tell her story.

In both Newton's and Hamilton's journals, on the other hand, slaves die anonymously because the voice of the steadfast and efficient captain prevails and reduces the narrative of their deaths to a few cursory remarks:

$9^{\text {th }}$ January [1751]: This day buried a fine woman slave, No. 11, having been ailing for some time, but never thought her in danger till within these 2 days; she was taken with a lethargick [sic] disorder, which they seldom recover from. Scraped the rooms, then smoked the ship with tar, tobacco and brimstone for 2 hours, afterwards washed with vinegar. (Newton, Journal 29)

20th April [1753]: This day buried 2 fine men slaves, Nos 27 and 43, having been ailing for some time, but not thought in danger. Taken suddenly with a lethargic disorder from which they generally recover. Scraped the men's rooms, then smoked the ship thoroughly with tar and tobacco for 3 hours, afterwards washed clean with vinegar. (Phillips, Crossing the River 116)

The slaves' deaths, meticulously recorded because of the economic loss incurred, is quickly followed by pragmatic measures such as the smoking and cleaning of the ship (a symbolic wiping out of the slaves from the historical archive) or, in other entries, neutral references to the weather. Both authentic and fictional entries are marked by the recurrence of identical words and the same detached tone but the date, gender, and quantity of slaves as well as their identifying numbers have been changed, along with the duration of the 
smoking of the ship and the information that slaves "generally" recover from the lethargic disorder (rather than "seldom”). Hamilton's version is therefore more deadly and tragic (slaves usually recover from that disorder but not these two), and the erasure of all traces of death from the historical archive requires more effort. For Wood, the slight changes to the original journal (in particular, substituting "a number that once did exist as a person into a number which now does not") have "almost limitless implications for the memory of slavery" (56) since they eradicate the trace of someone who existed and suffered and replace it with a fiction that does not prevent the slaves from being numbered. Wood argues that by destroying "that one small vestige of historical identity" slaves possessed - their numbers-Phillips removes them from their place in the historical archive (58). One could argue contrarily that the novelist preserves the real victims' integrity by changing their numbers for the slaves and their names for the members of the crew when transferring them to a fictional creation. In both cases, the reader is struck by the predominance of numbers (to refer to quantities, identities, and durations) and the stark efficiency of verbs unaccompanied by personal pronouns ("taken," "scraped," "smoked," "washed") that erase all signs of humanity and responsibility. Thereby, the slaves disappear from the historical archive and leave no trace in the memory of the slave trade.

The comparison of the logbooks reveals Phillips' great loyalty to the authentic archive despite a few adjustments and the efficiency of his pastiche, the effect of which silences the victims in official historical documents. By closely echoing the original journal, Phillips bears witness to the calamity of the slave trade and exposes the two captains' inhumanity while the minimal changes draw attention to the fictionality of Hamilton's logbook, thereby alerting the reader to the textuality and potential artifice of any document, including historical ones. The fictional letters are marked by a more intricate case of bricolage which combines pastiche and creation. Hamilton's letters faithfully reproduce or imitate extracts from Newton's letters to his wife but Phillips mixes several letters and transforms them in such a way as to let cracks appear in the portrait of the slave captain. 


\section{Letters to a Wife: A Technique of Montage and Collage}

In the acknowledgements to Crossing the River, Phillips refers only to the 1962 edition of Newton's journal, edited by Bernard Martin and Mark Spurrell, in which some entries are interrupted by extracts, enclosed in square brackets, of letters written by Newton and sent to friends or his wife. In "Crossing the River," two of Hamilton's letters are enclosed in brackets but they appear in full rather than as fragments. In his paratext, Phillips does not mention Letters to a Wife, a selection of the correspondence between Newton and his wife during his three voyages between 1750 and 1754 that he published in 1794. Letters to a Wife is remarkable for the way Newton constantly declares his love for his wife in an expansive and sometimes mawkish tone that contrasts with the rigidity of his journals. Despite not mentioning this volume, Phillips borrowed many passages from these letters, which he cut and pasted without respect for chronology. The two letters written by Hamilton are dated 10 January 1753 (when he is at sea) and 25 April 1753 (when he is in West Africa), whereas Newton's letters were written before his departure from Liverpool, after his arrival in Antigua, and when he was at sea headed toward Liverpool. The result is a montage and collage of passages from more than a dozen letters by Newton, whose sentences have been slightly altered and reorganized:

$8^{\text {th }}$ January [1751]: No one, who has not experienced it like me, can conceive the contrast between my present situation, distracted with the noise of slaves and traders, suffocated with heat, and almost chop-fallen with perpetual talking; and the sweet agreeable evenings I have passed in your company. (Newton, Letters 48)

$25^{\text {th }}$ April [1753]: Those, myself aside, who have experienced pleasant and agreeable evenings in your company, could never imagine the contrast between such sweet times, and the present miserable situation. I am continually assaulted by the combined noises of slaves and traders; suffocated by heat; and subjected to perpetual talking, the greater part of it to no serious purpose. (Phillips, Crossing the River 118) 
While Newton starts with the negative (his present situation, the noise, the heat) and ends with his pleasant memories of home, Hamilton phrases it the other way round, first focusing on his sweet memories of home and only then referring to the present conditions. Thus, Hamilton's fictional account communicates a more striking longing for the comforts of home and reveals a captain who is more vulnerable than his authentic model, thereby destabilizing the masculine clichés associated with slave trade figures. Another letter includes a passage which is similar to one in Crossing the River:

$29^{\text {th }}$ March [1751]: I give and take a good deal of raillery among the sea-captains I meet with here. They think I have not a right notion of life, and I am sure they have not. They say I am melancholy; I tell them they are mad. They say, I am a slave to one woman, which I deny; but can prove that some of them are mere slaves to a hundred. They wonder at my humour; I pity theirs. They can form no idea of my happiness; I answer I think the better of it on that account; for I should be ashamed of it, if it was suited to the level of those who can be pleased with a drunken debauch, or the smile of a prostitute. We shall hardly come to an agreement on these points; for they pretend to appeal to experience against me. (Newton, Letters 57-58; emphasis in original)

$10^{\text {th }}$ January [1753]: I take a good deal of raillery among the seacaptains, for they know I have not a secure knowledge of life, and I know they have not. They claim I am melancholy; I tell them they have lost their wits. They say I am a slave to a single woman; I claim they are a slave to hundreds, of all qualities. They wonder at my lack of humour, I pity theirs. They declare they can form no idea of my happiness, I counter with knowledge that being pleased with a drunken debauch, or the smile of a prostitute, can never give one such as I pleasure. They pretend, all the while, to appeal to experience against me, but I stand firm. (Phillips, Crossing the River 109; emphasis in original) 
Phillips copies the binary rhetorical construction of the original, relentlessly marking the stark opposition between other sea captains and Hamilton ("They claim"/“I tell them"; "They say"/“I claim"; "They wonder"/“I pity”), while at the same time appropriating the metaphorical use of the word "slave" which contrarily points to a blurring of categories and a "mutability of identities" (Ledent 58). I argue that by transforming a revolting historical reality into a romantic cliché, Newton and Hamilton trivialise the trauma of slavery. ${ }^{12}$ However, Phillips' replication of the metaphor exposes the trivialisation through his juxtaposition of the captain's sentimental letters (and his use of the cliché) with the journal in which the slaves are suffering victims, sold and bought, subjected to abuse, disease, and death - a situation quite unlike that of the devoted husband.

In the previous examples, the novel's close borrowings guarantee the accuracy of the eighteenth-century language used and testify to the text's faithfulness to the historical truth. However, Phillips is a creator as well as a bricoleur. Beyond the many echoes they include, the letters contain additions to the originals in the form of allusions to Hamilton's sense of inadequacy and references to his father (Phillips, Crossing the River 118-19). Newton's father died in England, and Newton learned of his death when he arrived in Antigua. Hamilton's father died two years before his first voyage and was buried in West Africa. Hamilton is more insecure than Newton although both are twenty-six years old when they make their first voyage. In one of his letters, Captain Hamilton tells his wife that Mr. Ellis, a slave trader who used to work for Hamilton's father and now sells slaves to the son, refuses to take Hamilton to his father's resting place and that one of his officers sees him as little more than a "gentleman-passenger" (109; emphasis in original). On the other hand, Newton writes to his wife in September 1751: "I am as absolute in my small dominions (life and death excepted) as any potentate in Europe. If I say to one, Come, he comes; if to another, Go, he flies" (Newton, Letters 110). His tone is much more assured than the fictional Hamilton's. His tone is much more assured than the fictional Hamilton's. Here and in Hamilton's long for home, Phillips introduces fissures in the stern figure of the slave 
captain, thereby deconstructing the myth of the overpowering white patriarch who has no doubts about the validity of his occupation.

In addition to these palpable - though limited-differences between Hamilton and Newton, other more substantial elements diverge and point to the specific agenda of Phillips' twentieth-century novel, which is quite understandably unlike that of an eighteenth-century work of nonfiction. Meaningful omissions in the section not only make the contemporary version creative but also reveal Phillips' purpose which is to reveal the partiality of the historical archive and hint at everything that is left unsaid. The other sections in the novel that involve former slaves and give them a voice ("The Pagan Coast" and "West") throw light on aspects of slavery that Captain Hamilton's journal and letters deliberately ignore.

\section{Creative Omissions}

Newton's first journal for 1750-51 includes a daily entry until 3 September 1750 , when the editors announce that when entries "are only weather or navigational details they are here omitted" (Newton, Journal 8). The second and third journals are "much abbreviated, including only entries which differ in kind or degree from the first voyage" (Newton, Journal xvii). These elisions are marked by asterisks between entries, and Phillips adopted these typographical notations when writing Hamilton's journal to indicate that entries are skipped. Readers of "Crossing the River" may interpret the asterisks as the sign of suppressed entries because they are inserted when the text moves, for instance, from 27 to 29 August, or from 29 August to 9 September. The entire section includes a total of thirty-six asterisks, while an authentic logbook would include an entry for each day. In addition to the suppression of whole entries, Phillips uses three periods at the beginning or end of some entries as typographical indications that parts of the text have been removed.

The notations (both asterisks and periods) suggest that the version of the journal with which readers are presented is edited and fragmented-the result of the intervention of an unidentified external hand. Hamilton's log is more partial than Newton's; there are twenty-four entries before elisions start 
in Newton's daily log and only sixteen entries for the same length of time in Hamilton's (with asterisks indicating missing days). The rhythm is therefore quicker in the fictional journal. Its entries are also shorter, which creates a more urgent tone. Events seem to happen in rapid succession so that, for instance, the first reference to slaves appears sooner, thus increasing the reader's sense of shock. Phillips also hastens Hamilton's voyage from Liverpool to Sierra Leone; it takes him only one month and twenty days to make the journey, while it took Newton two months and eight days.

The holes in Hamilton's logbook seem to point to a greater hole related to all that is written out of the history of slavery and therefore not remembered. Ward suggests that in the gaps "we can perhaps sense the unspoken or missing parts of this past, such as the voices, or stories, of the slaves (and of other, poorer, crew members), of whom we hear nothing" (Caryl Phillips 53). Hamilton refers to insurrections (Phillips, Crossing the River 111, 114) and a "conspiracy" (124), which are evidence of dissent, and to indistinct "noises" (118) — another dehumanizing word - as well as "talking" (118), "clamour" (121), and "melancholy lamentations" (124), which echo the "moaning" of the Louisiana blacks on board the ship sailing for Africa in Part I (14), but the actual words and narratives of the slaves and sailors are absent. In a footnote to a letter written on 26 January 1753 , Newton notes that the slave trade is "abounding with enormities which I have not mentioned" (Letters 158), and in a letter of 1 March 1754, he writes to his wife: "There are other reasons for my concern, which I need not mention to you" (Letters 250). These blanks hide violent and traumatic experiences which remain unknown to the captain's wife and erase a whole dimension of history.

The greatest gap in Hamilton's journal lies in the final ellipsis. While Newton's logbook follows the full route of the triangular slave trade from Liverpool to Africa, Antigua, and back to Liverpool, the journal in Crossing the River stops, with the following sentence, as the ship is leaving Africa: "We have lost sight of Africa" (124). The narrative is "suspended" just as the captain is suspended between Africa and America or the West Indies (Ward, Caryl Phillips 55), and the reader is thus offered only one part of the triangular voyage. This abrupt stop can be interpreted as a sign that the first 
part of the journey has ended (with the ship now "fully slaved" [Crossing the River 115]) and the narrative has therefore completed a stage. I argue that the three periods followed by a blank as emblematizing the silence to which the trauma of deterritorialization condemns the fettered African victims in the cargo hold. Interestingly, the last sentence of the section is followed by the title of the next part, "Somewhere in England," thus pointing to the elision of the second part of the triangular trade and moving directly to the third journey and return to England. In addition, the fourth narrative starts with the words "JUNE 1942 / They arrived today" (129), which may act as a response to "We have lost sight of Africa." The change in perspective from "we" to "they" allows readers to imagine that "they" could be the slaves of the Duke of York emigrating to England (although "they" are the GIs during World War II). The connection between the two narratives emphasizes the continuity between the legacy of slavery and the contemporary racism suffered by Black people in Britain and the United States, which is emblematized by Travis' situation in the last section. In "Somewhere in England," the Black GI is confronted with racism in the American army (the white officer says "these boys" are "different" [145]) and in the English village where he is stationed. When Travis marries a white woman from the village, he is told he will not be allowed to go back to the segregated Southern US with her, and when her child is born, she is forced to abandon him because of the color of his skin.

One may also interpret the third section's abrupt halt as an indication that poetic justice has been served, with "the ill-humoured slaves" (124) potentially having led a successful insurrection (unlike the failed one they had been preparing the day before) and the captain having been overthrown and killed; the "hard wind" and "lofty sea" (124) mentioned in the last entry having potentially led to the capsize of the ship; or Hamilton's "small fever" (124) having gotten the better of him. The open ending thus leaves room for the reader's interpretation as is often the case in a postcolonial or postmodernist fictional text. Newton's journal, on the other hand, is completed and then followed by two more journeys and journals. Phillips' elisions in "Crossing the River" draw attention to the silence to which the 
slaves are condemned in Newton's and Hamilton's journals and in the historical archive in general, where the victims' stories are not (or are only fragmentarily) recorded. By refusing to fill in the gaps and creating more holes, Phillips exposes the partiality of the archive.

\section{Interpreting the Hybrid Result}

While pastiche and unmarked quotations grant a historical authenticity to Crossing the River's fictional journal, there probably exist other reasons to justify this process of extensive appropriation. As Wood suggests, Phillips' creation can be considered as a contemporary and "diasporic equivalent" of Pierre Menard's contemporary version of Don Quixote as fictionally reviewed in Jorge Luis Borges' famous 1939 essay "Pierre Menard, Author of the Quixote" (Wood 55). Menard rewrites chapters from the first part of Cervantes' book word for word, but the fictional reviewer argues that, although the signs are the same, the signifieds are altered because the context of reading has changed and therefore the references and allusions are understood differently, just as the style and themes are received differently by the contemporary reader. ${ }^{13}$ However, Phillips' creation differs from Menard's in that it contains deviations from the original and the fictional journal and letters are inserted within a novel. As a novelist, Phillips is able to offer a multiplicity of views and experiences about slavery and the slave trade, and I agree with Maroula Joannou that his changes to the historical archive (Newton's journal and letters) reveal his awareness of "the fictionality of all textual representation" (Joannou 208).

As mentioned earlier, Phillips borrowed extensively from original sources for Cambridge, in which he quotes whole sentences from the eighteenthcentury slave narrative The Interesting Narrative of the Life of Olaudah Equiano (1789) as well as nineteenth-century journals ${ }^{14}$ with the aim of capturing an authentic voice and revealing the inadequacy of relying upon a single source or standard account. An important difference between Cambridge and "Crossing the River" is that the former novel is marked by an intertwining of many different sources and is therefore "a hybrid, a syncretic fabrication" (O’Callaghan 40), while the later narrative draws mainly on a 
single source, which makes it less polyphonic, despite the duophony of the matter-of-fact journal and the heartfelt letters on the one hand and the bidirectional temporal dimension on the other: the eighteenth-century English voice is relayed by a twentieth-century Caribbean-English writer. Phillips' friend Paul Edwards, an expert in eighteenth-century literature, read a first draft of Cambridge and sent his reaction to the novelist on 10 August 1990:

The Cambridge section uses so much material from Equiano and other sources in a wholly undisguised way that I doubt the value of the narrative. It is not as you thought, simply a problem of plagiarizing your sources, I think rather that the narrative degenerates into easily recognizable pastiche, a kind of impersonal patchwork with little contemporary value, since the original sources have said it all already. I think that the narrative of Cambridge must derive much more from your own imagination, but as it stands, what you do is repeat material from the past. That's not what a modern novelist must do with material like this . .., which is to make a new thing. (qtd. in Eckstein 7071)

Although Phillips' method in Crossing the River differs from that in Cambridge in that only one section of the book directly borrows from historical material, Edwards' severe reproach may be partly addressed to that section. Such loyalty to previously published work risks granting further authority to an archive that already lets the voices of white masters dominate and leaves slaves chained and silenced in the hull. Yet Phillips countered that, in Cambridge, he was rewriting "material which is largely (though by no means totally) inaccessible to the general reading public" and that he hoped that the memory of his fictional character might linger in the minds of the readers and "send them back to the original sources to find out more" (qtd. in Eckstein 71-72). He wanted to awaken readers to some aspects of history that may have been insufficiently known and the same could be said about Crossing the River. The "contemporary value" of the text therefore rests in its preservation and transmission of traces of the past, inserted within a 
fictional framework that targets readers other than historians or people used to reading historical documents on slavery.

Phillips' insistence that he draws from material "largely inaccessible to the general public" raises the question of reception: most readers will probably not notice the borrowed quotations as they will not be familiar with Newton's journal and will not compare the two documents. They will register the pastiche because the narrative imitates the style of logbooks but will approach the narrative as a fictional text crafted by a novelist. Only the expert reader (who does not seem to be Phillips' ideal reader since his letter to Edwards references his concern with "the general reading public"), specialists of eighteenth-century slave documents, or Phillips scholars might be tempted to compare the hypotext and hypertext and therefore discover the extent of the echoes. The effect of the borrowings therefore greatly differs according to the status of the reader. A reader who is familiar with Newton's journal and letters might not, like Edwards, be convinced by the "value of the narrative" because of its closeness to the original (qtd. in Eckstein 70-71) or else s/he might find interest in the crafty recycling of eighteenth-century documents within a twentieth-century fictional framework, while a non-specialist reader, unaware of the borrowings, might concentrate on what the section reveals of the horrors of the slave trade through what they would identify as a mainly invented text.

Wood, one of Phillips' expert readers and his fiercest detractor, strongly contests Phillips' appropriation of Newton's text. He argues that Phillips fails to transform the authentic journal into a new creation and that his pastiche "reduce[s] the complexities and complicities of the original" (59). Wood uses precise examples to compare the two versions and asserts that Phillips' version "damage[s] Newton's original" through its minor alterations of numbers, dates, and names and the "process of reduction" (62), his term for the deletion, via ellipses, of words, segments, or whole sentences. $\mathrm{He}$ contends that the inclusion of this material in the original made Newton's "terrifying mentality" more blatant (59) and the absence of it in the fictional version ends up eroding "the bizarre contradictions which inflect Newton's own voice" (63). According to Wood, Phillips cannot "invent anything more 
powerful than the words Newton has already made/written/invented/recorded" because the eighteenth-century slave captain's words "have an authority which a late twentieth-century consciousness desperate to reclaim the past cannot mimic" (54). Wood finds fault not with the notion that Phillips borrowed extensively from Newton's journal and letters without adding his own inventions (which is Edwards' main criticism), but that Phillips, as a fiction writer, distorted (even slightly) the historical documents.

Wood may dismiss Phillips' work because he posits himself as "a custodian of the historical archive" (Joannou 208) which needs to be preserved in its sheer abomination and exactitude, whereas Phillips exercises his rights as a novelist to (barely) deviate from the hypotext and thus point to its instability. It is probably because of the minor alterations to the original and because the section is inserted in a novel that Phillips is able to throw "into doubt the very process of recording the history of slavery" (Wood 53). The change of dates in the fictional logbook (which propels several of Newton's entries from 1750 or 1751 forward to 1752 or 1753) and the blending of entries from several of Newton's voyages testify to the process of fictionalization and unsettle the supposed solidity of dates in the historical archive. The near repetition of Newton's entries by a fictional Hamilton some two years after they were first written also points to the recurrence of the horror and trauma of slavery year after year, with each new voyage taking place in similar atrocious circumstances and erasing the specificity of each individual death and tragedy. The haunting and nightmarish repetition of history is best emblematized by the pastiche of Newton's entry for 11 December 1752. The original reads: "Put the boys in irons and slightly in the thumbscrews to urge them to a full confession" (Newton, Journal 71). Hamilton's entry for 2 April 1753 reads: "Put two in irons and delicately in the thumbscrews to encourage them to a full confession" (Phillips, Crossing the River 114). This is repeated, in italics, in the epilogue some two hundred and fifty years later (235) and suggests that the horrors of slavery are not forgotten. I interpret Phillips' deliberate change of dates and shift from "the boys" to "two" and "slightly" to "delicately"- this adverb applied to a ghastly 
act of torture ringing like an unbearable provocation - as a sign that Hamilton is recording yet another instance of torture eerily similar to the one performed by his predecessor. The text thus points to the nauseating recurrence of violence over the years.

In her analysis of Cambridge, Evelyn O'Callaghan writes that Phillips' extensive word-for-word quotations prove that he "has gone to great pains to establish the historical 'authenticity' of his fiction" but that his goal is to focus "attention on the connection between the fictional and historical narratives" (39). As theoreticians of historiography like Hayden White establish, historical documents are at once subjective, impartial, and made up of narrative, and therefore bear similarities with fiction. By inserting unaltered parts of a historical document in a novel, Phillips performs two apparently incompatible moves. On the one hand, his faithfulness to the brutal words and indifferent tone of Newton's original text directly exposes the common reader (who might not be as familiar with such documents as experts) to the stark cruelty of slavery as implemented by the British who, for a long time, failed to confront these dark hours of their history. On the other hand, the undifferentiated mixture of authentic quotes and invented fragments and the close proximity of this hybrid narrative to the openly fictional portions of the novel leads to a blurring of the frontiers between fiction and history and encourages readers to pay attention to the constructed and manipulative nature of historical texts. Phillips' use of Newton's material is valuable for the way it alerts readers to these two aspects.

Finally, Hamilton's journal should be considered in relation to the other narratives in the novel, as its impersonality and casualness contrast with the emotional tone of Martha's introspective story that precedes it and provides "access to the affective dimension of slavery" (Boutros 187). "West" alternates between third- and first-person narration to relate the painful tale of a slave woman who is separated from her husband and daughter in a slave auction and never sees them again. Hamilton's dehumanized log, which offers the perspective of a white slave captain obsessed with computing figures, is therefore "a shock after the human pathos and tragedy of Martha's story" (Low 137). This abrupt shift in tone and focalisation makes Hamilton's 
pastiche all the more chilling and disturbing. Moreover, the generic traits of the journal differ from how third-person omniscient narration allows Part I's Edward Williams to justify his involvement in the slave trade (Edward is portrayed as a reluctant slaveholder who frees his slaves and sends them to Liberia, but the internal focalisation reveals the extent of his self-deception and silences about his true story) as well as how Nash's letters in the same section present a former slave's version of the vile traffic- - views which are deafeningly ignored in the third section. The various narratives and perspectives proffered throughout the novel complement each other in the way they "expose the complicity of narrative in silencing or repressing something that resists being said" (Kowaleski-Wallace 99). As a result, Phillips' creation invites readers to reflect on the relationship between fiction and history, between narrative and the "ghastly authenticity" (Wood 64) of Newton's historical journal. Despite what Wood claims, re-inscribing Newton's logbook within a contemporary and fictional framework also offers a way to preserve even the most shameful events of the past from the forces of amnesia. Phillips thus "resist[s] the temptation to leave the reader with the sense that the story has been told, consigned to the past; that it has been taken care of and can therefore now be forgotten" (Craps 6). On the contrary, he demonstrates that history needs to be questioned anew and that fiction-in its great variety of forms, including pastiche, collage, and bricolage-is a valuable medium with which to perform this task. Phillips' exhumation of the historical archive shows his willingness to interrogate it and not let it rest, to expose its partiality and constructedness, and assert the necessity of imagining new ways of recording the past that allow a chorus of silenced voices to be heard.

\section{Notes}

${ }^{1}$ Genette defines hypertextuality as "any relationship uniting a text B (which I shall call the hypertext) to an earlier text A (I shall, of course, call it the hypotext), upon which it is grafted in a manner that is not that of commentary" (5).

${ }^{2}$ Ilona and Thomas argue that Phillips probably drew inspiration from other authentic sources apart from Newton's logbook and letters. They refer to 
journals by voyagers and travellers such as Sir Francis Drake, Sir Richard Hawkins, and Richard Haklyut (Ilona 3; Thomas 42). Phillips confirmed that he read many logbooks in a 2016 interview ("Crossing" 327).

${ }^{3}$ In an interview with Schatteman, Phillips reveals he read over two hundred books before composing The Nature of Blood ("Disturbing" 61): "[A]s the novel became increasingly fragmented, it felt okay to have parts of it that were influenced by this book or by that text, some of which I do acknowledge and some of which I don't acknowledge" (57).

${ }^{4}$ In particular, Kowaleski-Wallace, Eckstein, O'Callaghan, Joannou, and Lanone.

${ }^{5}$ In his autobiography My Bondage and My Freedom, Douglass shares his outrage at "expressions of surprise that black people could feel familial love as passionately as did white" (Meer 95).

${ }^{6}$ This narrative resonates with Morrison's Beloved in which a former slave woman is haunted by the ghost of the daughter she herself murdered to prevent her from being recaptured after they fled to a free state.

7 These two aspects are nevertheless interrelated as, according to Lenz, the "eighteenth-century sentimentalism and celebration of the bonds of the middle-class family" are exposed as "the reverse side of the spirit of capitalism, of the economic rationalism of the time" (247).

${ }^{8}$ It is interesting to note that Phillips chose for his fictional slave ship captain the name of the third mate in Newton's journal, a name whose last syllable (ton) echoes Newton's name. Although Hamilton is a fairly common name, it may recall Alexander Hamilton (1755-1804), one of the Founding Fathers of the United States, who was born out of wedlock on the island of Nevis in the West Indies (Phillips was born in St. Kitts, which forms a federation with Nevis) to James Hamilton (who bears the exact same name as the fictional slave captain) and a married woman. Alexander Hamilton's mother died when he was a child (like the fictional Hamilton's), a few years after Alexander's father had abandoned them. In 1785, the historical Hamilton cofounded the main anti-slavery organization in New York.

9 Just before this episode, Phillips' captain refers to the weather in a similar tone: "At sunrise, a snow and a sloop, both French, anchored at Leeward. Close dirty weather, and a great sea tumbling in" (116). Birat rightly notes, however, that Hamilton sometimes "comments upon natural phenomena in a highly impressionistic, almost poetic style" that contrasts with the brutality of his remarks "about the way he treats disobedient sailors and slaves" (98). The log is therefore hybrid in its mixture of cold-bloodedness and poetry, thus complicating the reader's response and "potentially creating a certain fascination with the mind of the captain in spite of the moral opprobrium generated by the context of slavery" (Birat 98).

${ }^{10}$ Wood argues contrarily that when it comes to the slaves in the fictional journal, "the account of extreme physical abuse is altered, and lessened" so that Hamilton emerges as "a softer figure" (60). 
${ }^{11}$ Goyal regrets Phillips' decision not to grant a voice to the slaves despite "meticulously reconstruct[ing] the voices of the masters with a great deal of fidelity to existing historical models" (20).

${ }^{12}$ Goyal remarks that Hamilton "hijack[s] the category of 'slave' for himself" (19).

13 For example, what, in the seventeenth century, appears as "a mere rhetorical praise of history" as being "the mother of truth" is considered an "astounding" idea in the twentieth century (Borges 51; emphasis in original). The fictional reviewer concludes: "Cervantes' text and Menard's are verbally identical, but the second is almost infinitely richer" (Borges 51).

${ }^{14}$ O'Callaghan refers to Monk Lewis' Journal of a West India Proprietor, Lady Nugent's Journal, and Mrs. Carmichael's Domestic Manners (O’Callaghan 36-38).

\section{Works Cited}

Arendt, Hannah. Eichmann in Jerusalem: A Report on the Banality of Evil. 1963. Penguin, 1994.

Bellamy, Maria Rice. "Haunting the African Diaspora: Responsibility and Remaining in Caryl Phillips's 'Crossing the River.'" African American Review, vol. 47, no. 1, Spring 2014, pp. 129-44. Project Muse, doi: 10.1353/afa.2014.0025.

Bewes, Timothy. "Shame, Ventriloquy, and the Problem of the Cliche in Caryl Phillips." Cultural Critique, vol. 63, Spring 2006, pp. 33-60.

Birat, Kathie. "Embodied Voices: Literacy and Empathy in Caryl Phillips's Crossing the River." Traversée d'une oeuvre: Crossing the River de Caryl Phillips, edited by Vanessa Guignery and Christian Gutleben. Cycnos, vol. 32, no. 1, 2016, pp. 89-105.

Borges, Jorge Luis. "Pierre Menard, Author of the Quixote." Labyrinths. 1962. Edited by Donald A. Yates and James E. Irby, translated by James E. Irby, New Directions, 1964, pp. 45-53.

Boutros, Fatim. "Bidirectional Revision: The Connection between Past and Present in Caryl Phillips's Crossing the River." Caryl Phillips: Writing in the Key of Life, edited by Bénédicte Ledent and Daria Tunca, Rodopi, 2012, pp. 175-90.

Craps, Stef. Postcolonial Witnessing: Trauma Out of Bounds. Palgrave Macmillan, 2013.

Douglass, Frederick. My Bondage and My Freedom. Miller, 1855.

Eckstein, Lars. Re-membering the Black Atlantic: On the Poetics and Politics of Literary Memory. Rodopi, 2006.

Genette, Gérard. Palimpsests. Literature in the Second Degree. 1982. Translated by Channa Newman and Claude Doubinsky, U of Nebraska P, 1997.

Gilroy, Paul. The Black Atlantic: Modernity and Double Consciousness. Harvard UP, 1993.

Goyal, Yogita. "Theorizing Africa in Black Diaspora Studies: Caryl Phillips' Crossing the River." Diaspora: A Journal of Transnational Studies, vol. 12, no. 1, Spring 2003, pp. 5-38. Project Muse, doi: 10.1353/dsp.2011.0033. 
Guignery, Vanessa, and Christian Gutleben, editors. Traversée d'une oeuvre: Crossing the River de Caryl Phillips. Cycnos, vol. 32, no. 1, 2016.

Ilona, Anthony. "Crossing the River: A Chronicle of the Black Diaspora." Wasafiri, vol. 11, no. 22, 1995, pp. 3-9.

Joannou, Maroula, “'Go West, Old Woman': The Radical Re-visioning of Slave History in Caryl Phillips's Crossing the River." Slavery and the Cultures of Abolition: Essays Marking the Bicentennial of the British Abolition Act of 1807, edited by Brycchan Carey and Peter J. Kitson, Brewer, 2007, pp. 195-213.

Kowaleski-Wallace, Elizabeth. The British Slave Trade \& Public Memory. Columbia UP, 2006.

Lanone, Catherine. "Repetition and Reckoning in Crossing the River." Traversée d'une oeuvre: Crossing the River de Caryl Phillips, edited by Vanessa Guignery and Christian Gutleben. Cycnos, vol. 32, no. 1, 2016, pp. 57-71.

Ledent, Bénédicte. “'Overlapping Territories, Intertwined Histories’: Crossculturality in Caryl Phillips's Crossing the River." Journal of Commonwealth Literature, vol. 30, no. 1, 1995, pp. 55-62.

Lenz, Günter H. "Middle Passages: Histories, Re-Memories, and Black Diasporas in Novels by Toni Morrison, Charles Johnson, and Caryl Phillips." Crabtracks: Progress and Process in Teaching the New Literatures in English: Essays in Honour of Dieter Riemenschneider, edited by Gordon Collier and Frank Schulze-Engler, Rodopi, 2002, pp. 235-52.

Low, Gail. "'A Chorus of Common Memory': Slavery and Redemption in Caryl Phillips's Cambridge and Crossing the River." Research in African Literatures, vol. 29, no. 4, Winter 1998, pp. 122-40.

Meer, Sarah. "Sentimentality and the Slave Narrative: Frederick Douglass." My Bondage and My Freedom." The Uses of Autobiography, edited by Julia Swindells, Taylor and Francis, 1995, pp. 89-97.

Morrison, Toni. Beloved. Knopf, 1987.

Newton, John. An Authentic Narrative. J. Johnson, 1764.

- The Journal of a Slave Trader (John Newton) 1750-1754, With Newton's Thoughts upon the African Slave Trade. Edited by Bernard Martin and Mark Spurrell, Epworth, 1962.

- Letters to a Wife. J. Johnson, 1793.

- Thoughts Upon the African Trade. J. Buckland and J. Johnson, 1788.

O'Callaghan, Evelyn. "Historical Fiction and Fictional History: Caryl

Phillips's Cambridge." Journal of Commonwealth Literature, vol. 29, no.

2, 1993, pp. 34-47.

Phillips, Caryl. The Atlantic Sound. 2000. Vintage, 2001.

—. Cambridge. Bloomsbury, 1991.

. "Caryl Phillips.” Interview by Pico Iyer. Schatteman, pp. 36-45.

Crossing the River. 1993. Vintage, 2006.

. "Crossing the River: A Conversation with Caryl Phillips." Interview by

Vanessa Guignery. Études Anglaises, vol. 69, no. 3, 2016, pp. 321-33, www.cairn.info/revue-etudes-anglaises-2016-3-page-321.htm. 
. "Crossing the River: Caryl Phillips Talks to Maya Jaggi." Interview by Maya Jaggi. Wasafiri, vol. 10, no. 20, 1994, pp. 25-29.

_. "Disturbing the Master Narrative: An Interview with Caryl Phillips (1999).” Interview by Renée T. Schatteman. Schatteman, pp. 53-66.

—. "Of This Time, of That Place: a Conversation with Caryl Phillips."

Interview by Jenny Sharpe. Schatteman, pp. 27-35.

- The Nature of Blood. Faber, 1997.

Schatteman, Renee T., editor. Conversations with Caryl Phillips, UP of Mississippi, 2009.

Steiner, George. Language and Silence. Essays on Language, Literature and the Inhuman. 1967. Atheneum, 1977.

Thomas, Helen. Caryl Phillips. Northcote / Writers and their Work Series, 2006.

Wallart, Kerry-Jane. "Decontextualizing Caryl Phillips's Crossing the River." Études Anglaises, vol. 69, no. 3, 2016, pp. 259-77, http://www.cairn.info/revue-etudes-anglaises-2016-3-page-259.htm.

Ward, Abigail. Caryl Phillips, David Dabydeen, and Fred D'Aguiar: Representations of Slavery. Manchester UP, 2011.

---. "Postcolonial Interventions into the Archive of Slavery: Transforming Documents into Monuments in Beryl Gilroy's Stedman and Joanna." Journal of Commonwealth Literature, vol. 45, no. 2, 2010, pp. 245-58.

White, Hayden. Tropics of Discourse. Essays in Cultural Criticism. John Hopkins UP, 1990.

Wood, Marcus. "Telling Tales: Fact as Fiction in Caryl Phillips's Abuse of Newton." Slavery, Empathy and Pornography, Oxford UP, 2002, pp. 5364. 